\title{
Pengelompokan Kabupaten/Kota di Jawa Timur berdasarkan Faktor-Faktor yang Mempengaruhi AIDS
}

\author{
Rakhmah Wahyu Maya, Anisa Ramadhan, Ikacipta Mega Ayuputri, Bambang Wijanarko Otok \\ Departemen Statistika, Fakultas Matematika, Komputasi, dan Sains Data \\ Institut Teknologi Sepuluh Nopember \\ J1. Arif Rahman Hakim, Surabaya 60111 Indonesia \\ e-mail: bambang_wo@statistika.its.ac.id
}

\begin{abstract}
Abstrak- Acquired Immune Deficiency Syndrome (AIDS) merupakan salah satu penyakit mematikan yang sampai saat ini belum ditemukan vaksin pencegahan atau obat untuk menyembuhkannya. AIDS disebabkan oleh virus Human Immunodeficiency Virus (HIV). Virus tersebut menyerang sistem kekebalan tubuh manusia. Sebagian besar orang tertular AIDS dikarenakan faktor pendidikan, kemiskinan, kesehatan yang didapatkan oleh masyarakat dan tenaga kesehatan. Oleh karena itu, peneliti menganalisis cluster faktor-faktor yang mempengaruhi penyakit AIDS di Jawa Timur pada tahun 2008. Analisis Cluster digunakan untuk mengelompokkan wilayah terjadinya penyakit AIDS. Penelitian tersebut membandingkan hasil pengujian analisis cluster Hirarki dengan menggunakan metode single linkage, complete linkage dan average linkage. Berdasarkan hasil analisis dapat diketahui bahwa jumlah cluster optimum yang terbentuk adalah 3 cluster. Selanjutnya dilakukan analisis manova. Berdasarkan hasil manova dapat diketahui bahwa faktor Cluster berpengaruh terhadap variabel yang mempengaruhi penyakit AIDS di Jawa Timur.
\end{abstract}

Kata Kunci-AIDS, Average linkage, Cluster analysis, Complete linkage, HIV, K-means, and Single linkage

\section{PENDAHULUAN}

Acquired Immune Deficiency Syndrome (AIDS) $A_{\text {merupakan salah satu penyakit mematikan yang sampai }}$ saat ini belum ditemukan vaksin pencegahan atau obat untuk menyembuhkannya. AIDS disebabkan oleh virus Human Immunodeficiency Virus (HIV). Virus tersebut menyerang sistem kekebalan tubuh manusia [1].

Pada 2012, Kemenkes memperkirakan ada 591.718 orang terinfeksi HIV di Indonesia. Namun pada akhir Maret 2014, hanya ada 134.053 orang diketahui terinfeksi HIV melalui tes sukarela. Pada waktu yang sama, 54.231 orang dilaporkan sudah sampai ke stadium AIDS dan 9.615 diketahui sudah meninggal dunia akibatnya. Sebagian besar orang tertular AIDS melalui hubungan seks dengan orang yang terinfeksi HIV, penggunaan jarum suntik bergantian dengan orang yang terinfeksi HIV, kelahiran oleh ibu yang terinfeksi [1]. Sebagian besar orang tertular AIDS dikarenakan faktor pendidikan, kemiskinan, dan kesehatan yang didapatkan oleh masyarakat.

Oleh karena itu, peneliti menganalisis cluster faktorfaktor yang mempengaruhi penyakit AIDS di Jawa Timur pada tahun 2008. Variabel yang digunakan adalah persentase penduduk yang tamat SMA di tiap kabupaten/kota di Jawa Timur, persentase penduduk miskin di tiap kabupaten/kota di Jawa Timur, persentase sarana kesehatan (RS dan puskesmas) di tiap kabupaten/kota di Jawa Timur. Analisis Cluster digunakan untuk mengelompokkan wilayah terjadinya penyakit AIDS. Penelitian tersebut membandingkan hasil pengujian analisis cluster Hirarki dengan menggunakan metode single linkage dan complete linkage dengan jarak Euclidean. Adanya penelitian ini diharapkan mengetahui untuk mengelompokkan wilayah terjadinya penyakit AIDS di Jawa Timur sehingga pemerintah dapat mengambil kebijakan yang tepat untuk mengatasi penyebaran penyakit AIDS yang terus meningkat.

\section{TINJAUAN PUSTAKA}

A. Statistika Deskriptif

Statistika deskriptif adalah serangkaian metode yang berkaitan dengan pengumpulan dan penyajian suatu data sehingga dapat memberikan informasi yang berguna tanpa adanya inferensia atau kesimpulan [2]. Pada penelitian ini akan digunakan metode statistika deskriptif rata-rata dan standart deviasi.

Rata-rata dari suatu data diperoleh dari membandingkan jumlah semua nilai datum dengan banyak nilai datumnya.

$$
\bar{x}=\frac{1}{n} \sum_{i=1}^{n} x_{i}
$$

dimana:

$$
\begin{array}{ll}
\bar{x} & =\text { Rata-rata } \\
x_{i} & =\text { Nilai data ke-i } \\
\mathrm{n} & =\text { Ukuran data (Banyak datum yang diamati) }
\end{array}
$$

Standar deviasi merupakan akar dari varians, dimana varians merupakah ukuran penyebaran data yang mengukur rata-rata jarak kuadrat semua titik pengamatan terhadap titik pusat (rataan).

$$
S=\sqrt{\frac{\sum_{i=1}^{n}\left(x_{i}-\bar{x}\right)^{2}}{n-1}}
$$

dimana:

$\mathrm{s}=$ Standar Deviasi

$x_{i}=$ Nilai data ke- $\mathrm{i}$

$\bar{x}=$ Rata-rata

$\mathrm{n}=$ Banyak data

\section{B. Analisis Cluster}

Analisis kelompok adalah satu metode yang digunakan untuk mengelompokkan objek-objek pengamatan menjadi beberapa kelompok berdasarkan karakteristik yang dimiliki dengan ciri tertentu relatif homogen, sehingga objek dalam kelompok memiliki kesamaan yang sama sedangkan objek antar kelompok tidak memiliki kesamaan yang sama [3]. Cluster atau pengelompokkan yang baik adalah cluster yang menunjukkan ciri sebagai berikut. 
1. Homogenitas (kesamaan) yang tinggi antar anggota dalam satu kelompok.

2. Heterogenitas (perbedaan) yang tinggi antar kelompok yang satu dengan kelompok yang lain.

Dalam analisis cluster, terdapat banyak metode untuk mengelompokan observasi ke dalam cluster. Secara umum metode pengelompokan dalam analisis cluster dibedakan menjadi metode hierarki dan non hierarki. Metode hierarki digunakan apabila belum ada informasi jumlah cluster yang dipilih. Sedangkan metode non hierarki bertujuan mengelompokan $\mathrm{n}$ objek ke dalam $\mathrm{k}$ cluster $(\mathrm{k}<\mathrm{n})$ dimana nilai $\mathrm{k}$ telah ditentukan sebelumnya [3]. Jarak Euclidien merupakan salah satu konsep jarak yang sering dipilih dalam analisis cluster dengan rumusan sebagai berikut.

$$
d(x, y)=\left[\left(x_{1}-y_{1}\right)^{2}+\left(x_{2}-y_{2}\right)^{2}+. .+\left(x_{p}-y_{p}\right)^{2}\right]^{1 / 2}
$$

Terdapat metode penggabungan yang bisa digunakan dalam analisis cluster hirarki yaitu sebagai berikut.

1. Single Linkage

Single linkage mepakan metode cluster non yang mana kelompok-kelompok dibentuk dari similarities/kemiripan yang paling besar. Menemukan jarak terpendek dalam dan menggabungkan objek-objek yang bersesuaian misalnya $U$ dan V, untuk mendapatkan claster (UV). Untuk langkah dari algoritma di atas jarak-jarak antara (UV) dan Cluster W yang lain dihitung dengan persamaan (4) sebagai berikut [3].

$$
d_{(u v) w}=\min \left(d_{u w}, d_{v w}\right)
$$

Berdasarkan persamaan (3), nilai $d_{U w}$ dan $d_{V w}$ secara berturut-turut adalah jarak terpendek antar cluster $\mathrm{U}$ dan $\mathrm{W}$ dan cluster $\mathrm{V}$ dan $\mathrm{W}$.

2. Complete Linkage

Complete Linkage merupakan metode cluster non hierarki yang memastikan bahwa semua item-item dalam satu Cluster berada dalam jarak paling jauh satu sama lain. Untuk langkah dari algoritma di atas jarak-jarak antara (UV) dan Cluster W yang lain dihitung dengan persamaan (5) sebagai berikut [3].

$$
d_{(u v) w}=\max \left(d_{u w}, d_{v w}\right)
$$

Berdasarkan persamaan (5), nilai $\mathrm{d}_{\mathrm{Uw}}$ dan $\mathrm{d}_{\mathrm{VW}}$ secara berturut-turut adalah jarak terpendek antar cluster $\mathrm{U}$ dan $\mathrm{W}$ dan cluster $\mathrm{V}$ dan $\mathrm{W}$.

\section{Average Linkage}

Prosedur pada average linkage hampir sama dengan single linkage maupun complete linkage, namun kriteria yang digunakan adalah rata-rata jarak seluruh individu dalam suatu Cluster dengan jarak seluruh individu dalam Cluster yang lain dengan rumus sebagai berikut [3].

$$
d_{(u v) w}=\frac{\sum_{i} \sum_{k} d_{i k}}{N_{(u v)} N_{w}}
$$

\section{Uji Bartlett}

Uji Bartlett digunakan untuk mengetahui ada atau tidaknya hubungan antar variabel dalam kasus multivariat. Hipotesis pengujian yang digunakan pada uji Bartlett adalah sebagai berikut [3].

$\mathrm{H}_{0}: \rho=\mathrm{I}$ (tidak terdapat hubungan antar variabel)

$\mathrm{H}_{1}: \rho \neq \mathrm{I}$ (terdapat hubungan antar variabel)
Statistik uji yang digunakan dalam uji ini dituliskan dalam Persamaan 7 berikut.

$$
\chi_{\text {hitung }}^{2}=-\left[n-1-\frac{2 p+5}{6}\right] \ln |R|
$$

$|R|$ merupakan determinan dari matriks korelasi, $n$ merupakan banyaknya sampel, dan $p$ banyaknya variabel. Jika gagal tolak $\mathrm{H}_{0}$, maka variabel tidak layak untuk dilakukan metode multivariat terutama metode analisis komponen utama dan analisis faktor. Jika ditetapkan taraf signifikan sebesar $\alpha$ maka tolak $\mathrm{H}_{0}$ yang artinya adanya hubungan antar variabel dengan ketentuan yaitu $\chi_{\text {hitung }}^{2}>\chi_{\alpha ; 1 / 2 p(p-1)}^{2}$.

\section{Uji Homogenitas}

Uji homogenitas digunakan untuk menguji homogenitas matriks varians-kovarians.Berikut ini adalah hipotesis yang digunakan.

$$
\begin{aligned}
& \mathrm{H}_{0}: \sum_{1}=\sum_{2}=\ldots=\sum_{g}=\sum \\
& \mathrm{H}_{1}: \text { minimal ada satu } \sum_{i} \neq \sum_{j}, i=1,2, \ldots, \mathrm{g} \\
& \text { Statistik uji: } \\
& M=\sum_{l=1}^{g}\left(n_{l}-1\right) \ln |S|-\sum_{l=1}^{g}\left(n_{l}-1\right) \ln \left|S_{l}\right| \\
& S=\frac{1}{N} \sum_{l=1}^{g}\left(n_{l}-1\right) \ln S_{l} ; N=\sum_{l=1}^{g}\left(n_{l}-g\right)
\end{aligned}
$$

dan,

$$
C^{-1}=1-\frac{2 p^{2}+3 p-1}{6(p+1)(g-1)}\left(\sum_{l=1}^{g} \frac{1}{\left(n_{l}-1\right)}-\frac{1}{\sum_{l=1}^{g}\left(n_{l}-1\right)}\right)
$$

Keterangan:

$n_{l}=$ banyak data sampel ke- $l$

$S_{l}=$ matriks sampel ke- $l$

$|\mathrm{S}|=$ nilai mutlak matriks $S$

$g$ = banyak populasi

Daerah kritis:

$$
\text { Tolak } \mathrm{H}_{0} \text { jika } M C^{-1}>\chi_{\left(\frac{1}{2}(g-1)(p+1)\right.}^{2}(\alpha) \text {, sehingga }
$$

\begin{tabular}{|c|c|c|}
\hline $\begin{array}{l}\text { Source of } \\
\text { Variation }\end{array}$ & Matrix of SSCP & $\begin{array}{l}\text { Degrees of } \\
\text { freedom }\end{array}$ \\
\hline Treatment & $B=\sum_{l=1}^{g} n_{l}\left(\bar{x}_{l}-\bar{x}\right)\left(\bar{x}_{l}-\bar{x}\right)^{\prime}$ & $g-1$ \\
\hline Error & $W=\sum_{l=1}^{g} \sum_{j=1}^{n_{l}} n_{l}\left(\bar{x}_{l j}-\bar{x}_{l}\right)\left(\bar{x}_{l j}-\bar{x}_{l}\right)^{\prime}$ & $\sum_{l=1}^{g} n_{l}-g$ \\
\hline Total & $B+W=\sum_{l=1}^{g} \sum_{j=1}^{n_{l}} n_{l}\left(\bar{x}_{l j}-\bar{x}\right)\left(\bar{x}_{l j}-\bar{x}\right)^{\prime}$ & $\sum_{l=1}^{g} n_{l}-1$ \\
\hline
\end{tabular}

dapat disimpulkan bahwa matriks varians-kovarians dari $l$ populasi adalah heterogen.

\section{E. MANOVA One-way}

MANOVA One-way merupakan pengembangan dari ANOVA One-way. One-way MANOVA digunakan untuk menguji apakah ke-g jenis populasi (dari satu populasi yang sama) menghasilkan vektor rata-rata yang sama untuk $p$ variabel perlakuan atau variabel dependen yang diamati dalam penelitian [3]. 
Prosedur pengujian MANOVA One-way adalah sebagai berikut.

$$
\begin{aligned}
& \mathrm{H}_{0}: \tau_{1}=\tau_{2}=\ldots=\tau_{g} \\
& \mathrm{H}_{1}: \text { minimal ada satu } \tau_{1}=\tau_{j}, i=1,2, \ldots, g
\end{aligned}
$$

Statistik uji :

dengan menggunakan nilai $F$ dari distribusi Wilks' Lambda Tabel 2. Distribusi dari Wilks' Lambda

\begin{tabular}{llc}
$\begin{array}{c}\text { No of } \\
\text { Varia } \\
\text { bles }\end{array}$ & $\begin{array}{c}\text { No of } \\
\text { groups }\end{array}$ & $\begin{array}{c}\text { Sampling distribution for multivariate normal } \\
\text { data }\end{array}$ \\
\hline $\mathrm{p}=1$ & $\mathrm{~g} \geq 2$ & $\left(\frac{\sum n_{l}-g}{g-1}\right)\left(\frac{1-\Lambda^{*}}{\Lambda^{*}}\right) \sim F_{(g-1), \sum n_{l}-g}$ \\
\hline $\mathrm{p}=2$ & $\mathrm{~g} \geq 2$ & $\left(\frac{\sum n_{l}-g-1}{g-1}\right)\left(\frac{1-\sqrt{\Lambda^{*}}}{\sqrt{\Lambda^{*}}}\right) \sim F_{2(g-1), 2\left(\sum n_{l}-g-1\right)}$ \\
$\mathrm{p} \geq 1$ & $\mathrm{~g}=2$ & $\left(\frac{\sum n_{l}-p-1}{p}\right)\left(\frac{1-\Lambda^{*}}{\Lambda^{*}}\right) \sim F_{p, \sum n_{l}-p-1}$ \\
$\mathrm{p} \geq 1$ & $\mathrm{~g}=3$ & $\left(\frac{\sum n_{l}-p-2}{p}\right)\left(\frac{1-\sqrt{\Lambda^{*}}}{\sqrt{\Lambda^{*}}}\right) \sim F_{2 p, 2\left(\sum n_{l}-p-2\right)}$
\end{tabular}

Dengan,

$$
\Lambda^{*}=\frac{|W|}{|W+B|}=\frac{\left|\sum_{l=1}^{g} \sum_{j=1}^{n_{t}}\left(x_{l j}-\bar{x}_{l}\right)\left(x_{l j}-\bar{x}_{l}\right)^{\prime}\right|}{\left|\sum_{l=1}^{g} \sum_{j=1}^{n_{l}}\left(x_{l j}-\bar{x}\right)\left(x_{l j}-\bar{x}\right)^{\prime}\right|}
$$

\section{F. Acquired Immune Deficiency Syndrome (AIDS)}

Acquired Immune Deficiency Syndrome (AIDS) adalah sekumpulan gejala dan infeksi yang timbul karena rusaknya sistem kekebalan tubuh manusia akibat infeksi virus HIV. Pada 2012, Kemenkes memperkirakan ada 591.718 orang terinfeksi HIV di Indonesia. Namun pada akhir Maret 2014, hanya ada 134.053 orang diketahui terinfeksi HIV melalui tes sukarela. Pada waktu yang sama, 54.231 orang dilaporkan sudah sampai ke stadium AIDS dan 9.615 diketahui sudah meninggal dunia akibatnya. Sebagian besar orang tertular AIDS melalui hubungan seks dengan orang yang terinfeksi HIV, penggunaan jarum suntik bergantian dengan orang yang terinfeksi HIV, kelahiran oleh ibu yang terinfeksi [1]

\section{A. Sumber Data}

III. METODOLOGI PENELITIAN

Data yang digunakan dalam laporan praktikum mengenai pengelompokan kabupaten atau kota berdasarkan faktor-faktor yang mempengaruhi AIDS di Jawa Timur pada tahun 2008 dari Tugas Akhir yang berjudul "Perbandingan Analisis Regresi Poisson, Generalized Poisson Regression dan Geographically Weighted Poisson Regression (Studi Kasus: Pemodelan Jumlah Kasus Aids di Jawa Timur Tahun 2008)" oleh Novia Assriyanti (1307100074). Data yang digunakan, diambil pada hari Jumat 6 April 2018 pukul 10.00 di Ruang Baca Jurusan Statistika ITS Surabaya.

\section{B. Variabel Penelitian}

Variabel dependen pada penelitian ini adalah faktorfaktor yang mempengaruhi penyakit AIDS di Jawa Timur Berikut variabel yang digunakan dalam penelitian.

Tabel 1 Variabel yang digunakan pada penelitian

\begin{tabular}{clll}
\hline Variabel & \multicolumn{4}{c}{ Keterangan } \\
\hline$x_{1}$ & $\begin{array}{l}\text { Persentase penduduk yang tamat SMA di tiap } \\
\text { kabupaten/kota di Jawa Timur. }\end{array}$ \\
$x_{2}$ & $\begin{array}{l}\text { Persentase penduduk miskin di } \\
\text { kabupaten/kota di Jawa Timur. }\end{array}$ \\
$x_{3}$ & $\begin{array}{l}\text { Persentase sarana kesehatan } \\
\text { puskesmas) di tiap kabupaten/kota di Jawa }\end{array}$ \\
& Timur. \\
$x_{4}$ & $\begin{array}{l}\text { Presentase tenaga medis di tiap kabupaten/kota } \\
\text { di Jawa Timur }\end{array}$ \\
\hline
\end{tabular}

C. Metode Analisis Data

Metode analisis yang digunakan dalam penelitian adalah sebagai berikut :

1. Mengumpulkan data sekunder.

2. Mengelompokkan variable ke dalam kelompok sebanyak yang ditentukan untuk analisis cluster teknik hierarki.

3. Mengelompokkan variable ke dalam kelompok sebanyak yang ditentukan untuk analisis cluster teknik non hierarki.

4. Melakukan analisis Manova berdasarkan kelompok yang telah terbentuk.

4. Menginterpretasi hasil analisis data dan membuat kesimpulan.

\section{IV.HASIL DAN PEMBAHASAN}

\section{A. Karakteristik Data}

Karakteristik data adalah analisis yang pertama kali dilakukan. Karakteristik data merupakan hasil analisis yang memberikan informasi tentang deskripsi data. Karakteristik dari data jumlah kasus AIDS di tiap Kabupaten/Kota di Jawa Timur pada tahun 2008.

\begin{tabular}{ccc}
\multicolumn{3}{c}{ Tabel 1 } \\
\hline Variabel & Mean & St.Deviasi \\
\hline $\mathrm{X}_{1}$ & 34,074 & 7,657 \\
$\mathrm{X}_{2}$ & 7,876 & 4,170 \\
$\mathrm{X}_{3}$ & 21,631 & 7,116 \\
$\mathrm{X}_{4}$ & 1,014 & 0,618 \\
\hline
\end{tabular}

Tabel 1 diatas menunjukan pada variabel $\mathrm{X}_{1}$ yaitu persentase jumlah penduduk yang tamat SMA/SMK di provinsi Jawa Timur sebesar 34,074. Nilai tersebut lebih rendah dari 50 dan memiliki variabilitas yang cukup besar. Hal ini menunjukan masih banyak penduduk di Provinsi Jawa Timur yang berpendidikan rendah. Nilai persentase penduduk miskin dibawah $10 \%$. Nilai tersebut memang dibawah nilai nasional, namun nilai 7,876 tersebut merupakan cukup besar jika dilihat dari jumlah penduduk Provinsi Jawa Timur yang terbesar kedua di Indonesia. Nilai variabel $\mathrm{X}_{3}$ dan $\mathrm{X}_{4}$ yang mengindikasikan sarana dan tenaga kesehatan masih rendah.

\section{B. Analisis Cluster Hierarki}

Analisis Cluster digunakan untuk mengelompokkan wilayah terjadinya penyakit AIDS. Berikut adalah analisis dan pembahasannya.

1. Single Linkage

Langkah pertama yang dilakukan adalah deteksi missing value dengan hasil sebagaimana Tabel 2 berikut. 
Tabel 2. Hasil Proses Missing Value Metode Single Linkage

\begin{tabular}{cccccc}
\hline \multicolumn{2}{c}{ Valid } & \multicolumn{2}{c}{ Missing } & \multicolumn{2}{c}{ Total } \\
$\mathrm{N}$ & Percent & $\mathrm{N}$ & Percent & $\mathrm{N}$ & Percent \\
\hline 38 & $100 \%$ & 0 & $0 \%$ & 38 & $100 \%$
\end{tabular}

Berdasarkan Tabel 2 dapat diketahui bahwa tidak terdapat missing value dengan persentase valid sebesar $100 \%$. Selanjutnya dilakukan analisis cluster dengan hasil sebagai beirkut.

\begin{tabular}{|c|c|c|c|c|c|c|}
\hline \multirow{2}{*}{$\begin{array}{c}\text { Stag } \\
\mathrm{e}\end{array}$} & \multicolumn{2}{|c|}{$\begin{array}{c}\text { Cluster } \\
\text { Combined }\end{array}$} & \multirow{2}{*}{$\begin{array}{c}\text { Coefficient } \\
\text { s }\end{array}$} & \multicolumn{2}{|c|}{$\begin{array}{l}\text { Stage Cluster } \\
\text { First Appears }\end{array}$} & \multirow{2}{*}{$\begin{array}{c}\text { Next } \\
\text { Stag } \\
\mathrm{e}\end{array}$} \\
\hline & $\begin{array}{c}\text { Cluste } \\
r 1\end{array}$ & $\begin{array}{l}\text { Cluste } \\
r 2\end{array}$ & & $\begin{array}{c}\text { Cluste } \\
r 1\end{array}$ & $\begin{array}{c}\text { Cluste } \\
r 2\end{array}$ & \\
\hline 1 & 28 & 29 & 2.518 & 0 & 0 & 4 \\
\hline 2 & 6 & 22 & 2.713 & 0 & 0 & 15 \\
\hline 3 & 2 & 10 & 4.225 & 0 & 0 & 7 \\
\hline$\vdots$ & $\vdots$ & $\vdots$ & $\vdots$ & $\vdots$ & $\vdots$ & $\vdots$ \\
\hline 35 & 1 & 7 & 96.786 & 34 & 33 & 36 \\
\hline 36 & 1 & 25 & 118.623 & 35 & 0 & 37 \\
\hline 37 & 1 & 31 & 119.27 & 36 & 0 & 0 \\
\hline
\end{tabular}

Berdasarkan Tabel 4 dapat diektahui bahwa kabupaten ke-28 dan ke-29 digabungkan menjadi satu cluster karena memiliki jarak terdekat, kemudian dilanjutkan kepada stage 2. Anggota cluster pada stage pertama ditambahkan kabupaten ke-6 dan ke-22, begitu pula sampai stage 37 . Pengelompokan juga dapat dilihat pada dendogram sebagaimana pada gambar 1 berikut.

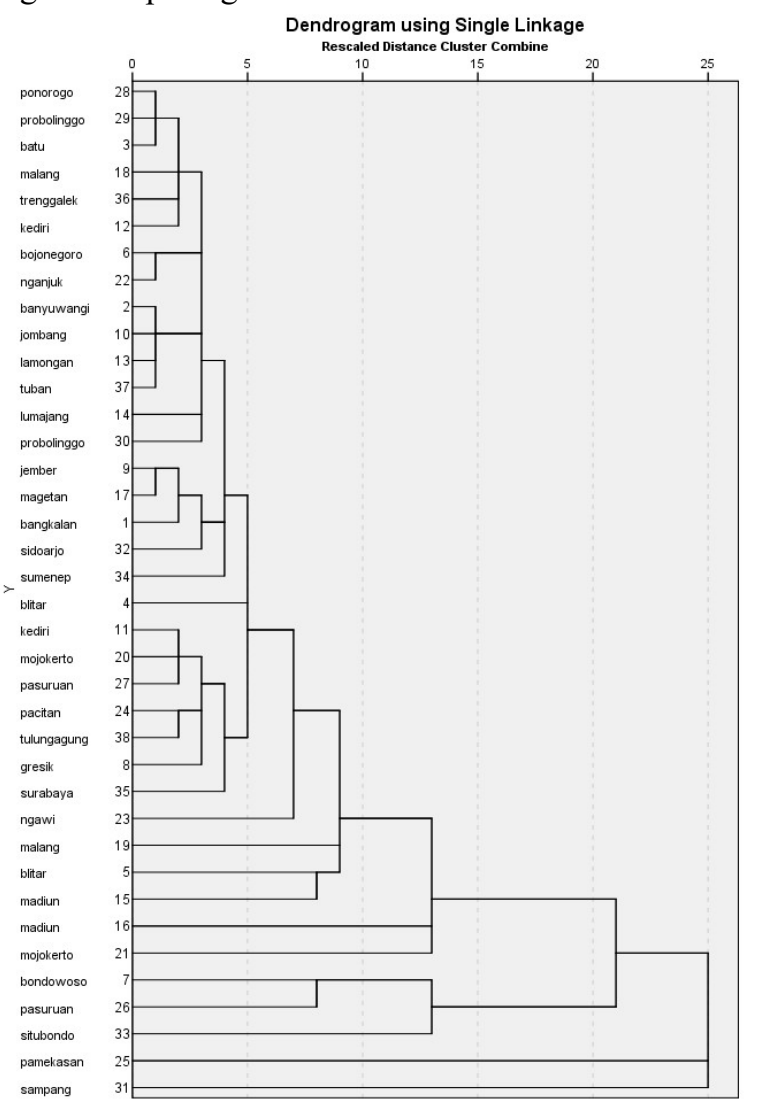

Gambar 1 Hasil cluster metode single linkage

Gambar 1 menunjukan dari 38 kabupaten/kota dapat terbentuk 37 hingga 2 cluster. Jika terbentuk dua cluster maka satu cluster beranggotakan satu anggota yaitu hanya kabupaten sampang. Hal ini menunjukkan menurut metode single linkage keempat variabel yang mempengaruhi jumlah kasus AIDS tersebut berbeda dari cluster lainnya yang beranggota 37 kabupaten/kota di Provinsi Jawa Timur.

2. Complete Linkage

Langkah pertama yang dilakukan adalah deteksi missing value dengan hasil sebagaimana Tabel 2 berikut.

Tabel 5. Hasil Proses Missing Value Metode Complete Linkage

\begin{tabular}{cccccc}
\hline \multicolumn{2}{c}{ Valid } & \multicolumn{2}{c}{ Missing } & \multicolumn{2}{c}{ Total } \\
$\mathrm{N}$ & Percent & $\mathrm{N}$ & Percent & $\mathrm{N}$ & Percent \\
\hline 38 & $100 \%$ & 0 & $0 \%$ & 38 & $100 \%$ \\
\hline
\end{tabular}

Berdasarkan Tabel 5 dapat diketahui bahwa tidak terdapat missing value dengan persentase valid sebesar $100 \%$. Selanjutnya dilakukan analisis cluster dengan hasil sebagai beirkut.

Tabel 6. Agglomeration Schedule Metode Complete Linkage

\begin{tabular}{|c|c|c|c|c|c|c|}
\hline \multirow{2}{*}{$\begin{array}{c}\text { Stag } \\
\mathrm{e}\end{array}$} & \multicolumn{2}{|c|}{$\begin{array}{c}\text { Cluster } \\
\text { Combined }\end{array}$} & \multirow{2}{*}{$\begin{array}{l}\text { Coefficient } \\
\text { s }\end{array}$} & \multicolumn{2}{|c|}{$\begin{array}{l}\text { Stage Cluster } \\
\text { First Appears }\end{array}$} & \multirow{2}{*}{$\begin{array}{c}\text { Next } \\
\text { Stag } \\
\mathrm{e}\end{array}$} \\
\hline & $\begin{array}{c}\text { Cluste } \\
r 1\end{array}$ & $\begin{array}{c}\text { Cluste } \\
r 2\end{array}$ & & $\begin{array}{c}\text { Cluste } \\
r 1\end{array}$ & $\begin{array}{c}\text { Cluste } \\
r 2\end{array}$ & \\
\hline 1 & 28 & 29 & 2.518 & 0 & 0 & 6 \\
\hline 2 & 6 & 22 & 2.713 & 0 & 0 & 11 \\
\hline 3 & 2 & 10 & 4.225 & 0 & 0 & 10 \\
\hline$\vdots$ & $\vdots$ & $\vdots$ & $\vdots$ & $\vdots$ & $\vdots$ & $\vdots$ \\
\hline 35 & 1 & 31 & 481.745 & 30 & 27 & 36 \\
\hline 36 & 1 & 3 & 987.383 & 35 & 33 & 37 \\
\hline 37 & 1 & 2 & 1326.484 & 36 & 34 & 0 \\
\hline
\end{tabular}

Berdasarkan Tabel 4 dapat diektahui bahwa kabupaten ke-28 dan ke-29 digabungkan menjadi satu cluster karena memiliki jarak terdekat, kemudian dilanjutkan kepada stage 2. Anggota cluster pada stage pertama ditambahkan kabupaten ke-6 dan ke-22, begitu pula sampai stage 37. Pengelompokan juga dapat dilihat pada dendogram sebagaimana pada Gambar 2 berikut.

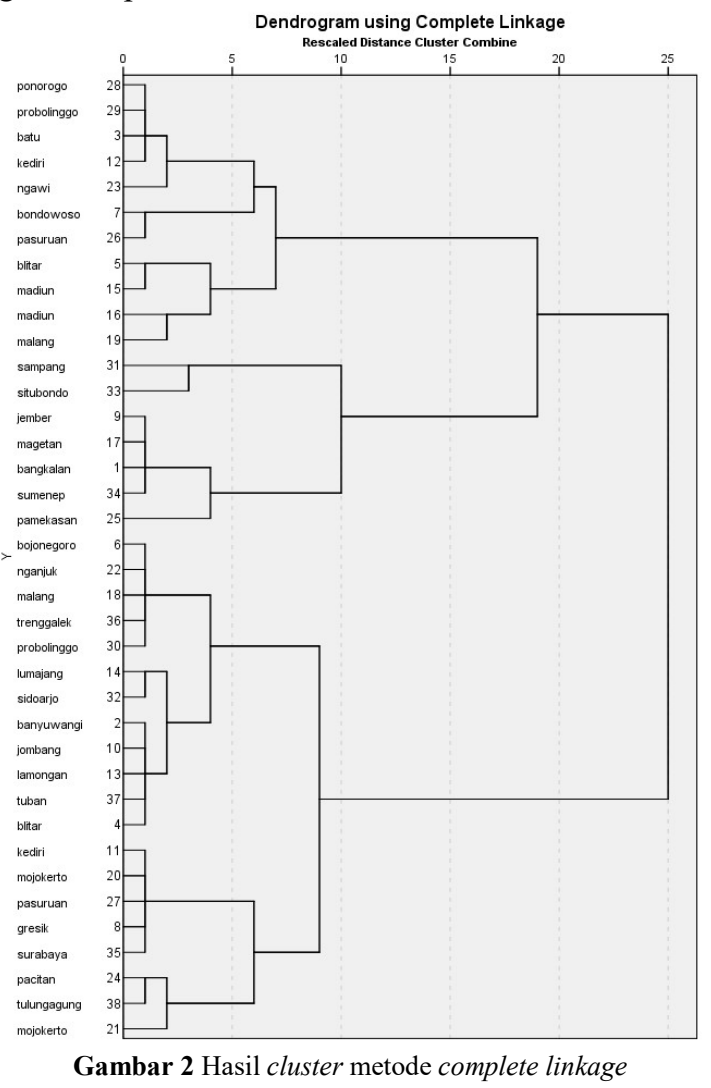

Gambar 2 menunjukan dengan menggunakan jarak yang sama tapi dengan metode berbeda menghasilkan pengelompokan yang berbeda. Jika terbentuk dua cluster maka satu cluster beranggotakan 18 kabupaten/kota dan cluster yang lain beranggotakan 20 kabupaten/kota.

3. Average Linkage

Langkah pertama yang dilakukan adalah deteksi missing value dengan hasil sebagaimana Tabel 3 berikut. 
Tabel 7. Hasil Proses Missing Value Metode Average Linkage

\begin{tabular}{cccccc}
\hline \multicolumn{2}{c}{ Valid } & \multicolumn{2}{c}{ Missing } & \multicolumn{2}{c}{ Total } \\
$\mathrm{N}$ & Percent & $\mathrm{N}$ & Percent & $\mathrm{N}$ & Percent \\
\hline 38 & $100 \%$ & 0 & $0 \%$ & 38 & $100 \%$
\end{tabular}

Berdasarkan Tabel 7 dapat diketahui bahwa tidak terdapat missing value dengan persentase valid sebesar $100 \%$. Selanjutnya dilakukan analisis cluster dengan hasil sebagai beirkut.

\begin{tabular}{|c|c|c|c|c|c|c|}
\hline \multirow{2}{*}{$\begin{array}{c}\text { Stag } \\
\mathrm{e}\end{array}$} & \multicolumn{2}{|c|}{$\begin{array}{c}\text { Cluster } \\
\text { Combined } \\
\end{array}$} & \multirow{2}{*}{$\begin{array}{l}\text { Coefficient } \\
\text { s }\end{array}$} & \multicolumn{2}{|c|}{$\begin{array}{l}\text { Stage Cluster } \\
\text { First Appears } \\
\end{array}$} & \multirow{2}{*}{$\begin{array}{c}\text { Next } \\
\text { Stag } \\
\text { e }\end{array}$} \\
\hline & $\begin{array}{c}\text { Cluste } \\
r 1\end{array}$ & $\begin{array}{c}\text { Cluste } \\
r 2 \\
\end{array}$ & & $\begin{array}{c}\text { Cluste } \\
r 1 \\
\end{array}$ & $\begin{array}{c}\text { Cluste } \\
r 2\end{array}$ & \\
\hline 1 & 28 & 29 & 2.518 & 0 & 0 & 5 \\
\hline 2 & 6 & 22 & 2.713 & 0 & 0 & 12 \\
\hline 3 & 2 & 10 & 4.225 & 0 & 0 & 7 \\
\hline$\vdots$ & $\vdots$ & $\vdots$ & $\vdots$ & $\vdots$ & $\vdots$ & $\vdots$ \\
\hline 35 & 5 & 7 & 302.769 & 33 & 30 & 36 \\
\hline 36 & 1 & 5 & 363.520 & 34 & 35 & 37 \\
\hline 37 & 1 & 25 & 577.179 & 36 & 31 & 0 \\
\hline
\end{tabular}

Berdasarkan Tabel 8 dapat diketahui bahwa kabupaten ke-28 dan ke-29 digabungkan menjadi satu cluster karena memiliki jarak terdekat, kemudian dilanjutkan kepada stage 2. Anggota cluster pada stage pertama ditambahkan kabupaten ke-6 dan ke-22, begitu pula sampai stage 37 . Pengelompokan juga dapat dilihat pada dendogram sebagaimana pada Gambar 3 berikut.

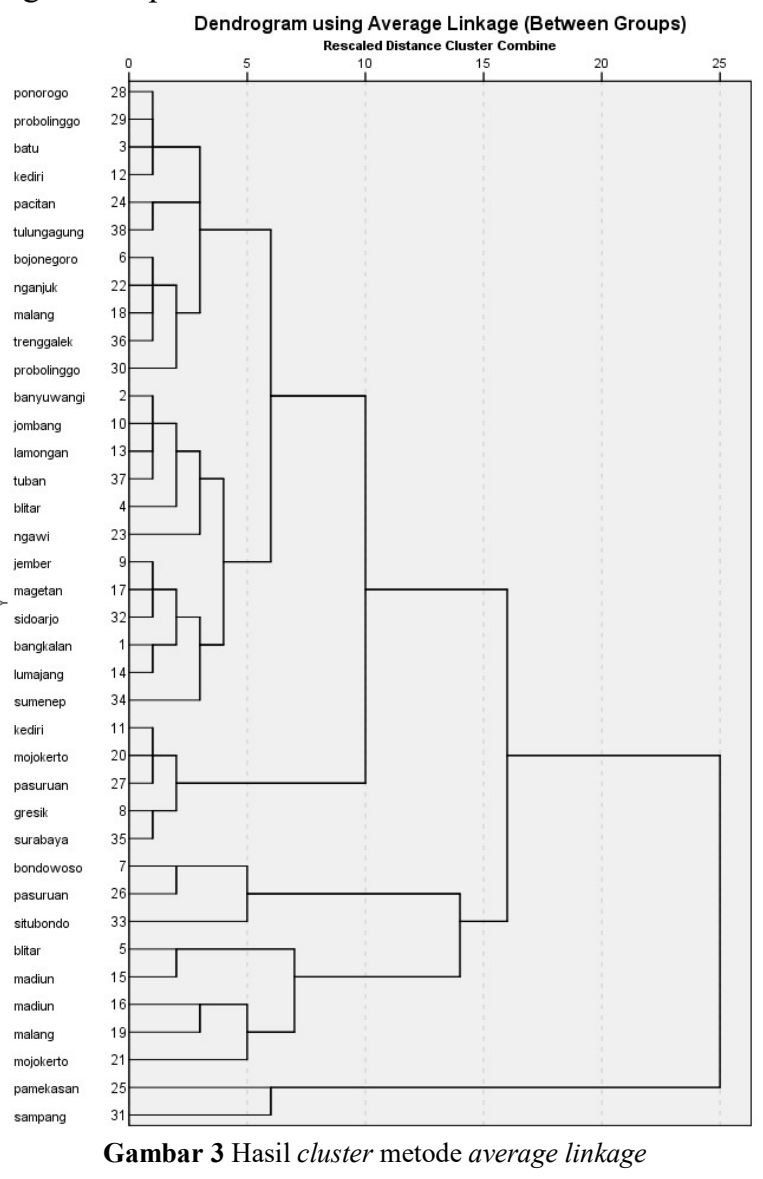

\section{Pemilihan Metode Terbaik}

Pemilihan metode terbaik dilakukan berdasarkan nilai pseudo F dan icdrate berdasarkan Tabel 9 berikut.
Tabel 9 Pemilihan Metode Terbaik

\begin{tabular}{cccc}
\hline Metode & $\begin{array}{c}\text { Banyaknya } \\
\text { Cluster }\end{array}$ & Pseudo-F & Icdrate \\
\hline Single & 2 Cluster & 4,337 & 0,336 \\
Linkage & 3 Cluster & 4,124 & $\mathbf{0 , 2 6 7}$ \\
& 4 Cluster & 6,891 & 0,285 \\
Complete & 2 Cluster & 9,651 & 1,429 \\
Linkage & 3 Cluster & 15,599 & 0,889 \\
& 4 Cluster & 14,258 & 0,609 \\
Average & 2 Cluster & 3,027 & 0,915 \\
Linkage & 3 Cluster & $\mathbf{1 8 , 1 1 3}$ & 0,885 \\
& 4 Cluster & 9,663 & 0,905 \\
\hline
\end{tabular}

Berdasarkan pada Tabel 9 dapat diketahui bahwa pada metode complete linkage dan average linkage mengahsilkan kesimpulan yg sama yaitu terbentuk 3 cluster sedangkan pada metode single linkage terbentuk 4 cluster. Sehingga dapat diketahui jumlah cluster yang optimal adalah 3 cluster.

D. Analisis Manova

Analisis MANOVA menggunakan kelompok yang telah diketahui melalui nilai pseudo-F. Kelompok pertama memiliki anggota Kabupaten Sampang, kelompok kedua adalah Kabupaten Pamekasan, kelompok ketiga adalah Kabupaten Situbondo, Bondowoso dan Pasuruan, sedangkan sisanya masuk kedalam kelompok keempat. Hasil analisis MANOVA terdiri dari uji asumsi distribusi normal, uji Bartlett, dan analisis MANOVA one way. Berikut adalah hasil analisis uji asumsi distribusi normal.

Tabel 10. Hasil Uji Distribusi Normal

\begin{tabular}{ccc}
\hline $\begin{array}{c}\text { Korelasi } \\
\text { Pearson }\end{array}$ & Nilai kritis & Keputusan \\
\hline 0,865 & 0,809 & tolak $\mathrm{H}_{0}$ \\
\hline
\end{tabular}

Taraf signifikan yang digunakan sebesar 0,05. Tabel 10 dapat diketahui bahwa nilai korelasi Pearson lebih besar dari nilai kritis, artinya data berdistribusi normal multivariat. Selanjutnya dilakukan pengujian Bartlett ntuk mengetahui hubungan antar variabel yang diperoleh hasil sebagai beirkut.

\begin{tabular}{cc} 
Taraf Signifikan & Keputusan \\
\hline 0,05 & Tolak $\mathrm{H}_{0}$
\end{tabular}

Tabel 11 menunjukkan bahwa p-value kurang dari taraf signifikan, artinya data ada hubungan yang signifikan antar variabel yang mempengaruhi penyakit AIDS di Jawa Timur. Selanjutnya adalah analisis manova yang diketahui hasil analisis adalah seperti berikut.

Tabel 12. Hasil MANOVA

\begin{tabular}{ccccc}
\hline $\mathrm{F}$ & $\mathrm{F}_{\text {tabel }}$ & $\begin{array}{c}\mathrm{P}- \\
\text { value }\end{array}$ & $\begin{array}{c}\text { Taraf } \\
\text { Signifikansi }\end{array}$ & Keputusan \\
\hline 8,167 & 1,827 & 0 & 0,05 & Tolak $\mathrm{H}_{0}$ \\
\hline
\end{tabular}

Tabel 12 menjelaskan bahwa nilai $\mathrm{F}$ lebih besar dari Ftabel dan p-value kurang dari 0,05. Hal tersebut dapat diartikan faktor Cluster berpengaruh terhadap variabel yang mempengaruhi penyakit AIDS di Jawa Timur, sehingga dilanjutkan analisis individu. 
Tabel 13. Hasil Uji Individu

\begin{tabular}{|c|c|c|c|}
\hline Variabel & P-value & $\begin{array}{c}\text { Taraf } \\
\text { Signifikansi } \\
\end{array}$ & Keputusan \\
\hline $\mathrm{X} 1$ & 0,020 & 0,05 & Tolak $\mathrm{H}_{0}$ \\
\hline $\mathrm{X} 2$ & 0,000 & 0,05 & Tolak $\mathrm{H}_{0}$ \\
\hline $\mathrm{X} 3$ & 0,000 & 0,05 & Tolak $\mathrm{H}_{0}$ \\
\hline X4 & 0,0113 & 0,05 & Tolak $\mathrm{H}_{0}$ \\
\hline
\end{tabular}

Informasi pada Tabel 13 dapat disimpulkan bahwa hasil pengelompokan cluster berpengaruh pada variabel yang mempengaruhi penyakit AIDS di Jawa Timur.

\section{KESIMPULAN DAN SARAN}

Berdasarkan analisis diatas dapat disimpulkan jumlah cluster optimum yang terbentuk adalah 3 cluster. Selanjutnya dilakukan analisis manova. Berdasarkan hasil manova dapat diketahui bahwa faktor cluster berpengaruh terhadap variabel yang mempengaruhi penyakit AIDS di Jawa Timur.

Dalam penelitian ini diharapkan agar lebih memahami materi yang dibahas, agar tidak terdapat kesalahan dalam pengolahan data ataupun dalam menginterpretasikannya. Panduan yang jelas dalam melakukan penelitian ini sangat penting serta dalam menganalisis data hasil pengamatan diperlukan kecermatan dan ketelitian

\section{DAFTAR PUSTAKA}

[1] Pasal 1 Peraturan Menteri Kesehatan Republik Indonesia Nomor 21 Tentang Penanggulangan HIV dan AIDS. Tahun 2013

[2] R. Walpole, Intoduction to Statistics, New York: Macmillan Publishing Co. Inc, 1995.

[3] R. Johnson and D. Wichern, Applied Multivariate Statistical Analysis, New Jersey: Pearson Education, 2007. 